\title{
Erythromycin Ethylsuccinate
}

National Cancer Institute

\section{Source}

National Cancer Institute. Erythromycin Ethylsuccinate. NCI Thesaurus. Code C47987.

The ethylsuccinate salt form of erythromycin, a broad-spectrum, topical macrolide antibiotic with antibacterial activity. Erythromycin ethylsuccinate diffuses through the bacterial cell membrane and reversibly binds to the 50S subunit of the bacterial ribosome. This prevents bacterial protein synthesis. Erythromycin ethylsuccinate may be bacteriostatic or bactericidal in action, depending on the concentration of the drug at the site of infection and the susceptibility of the organism involved. 